\title{
USE OF ARTIFICIAL NEURAL NETWORKS FOR PROGNOSIS OF CHARCOAL PRICES IN MINAS GERAIS
}

\author{
Luiz Moreira Coelho Junior ${ }^{1}$, José Luiz Pereira de Rezende ${ }^{2}$, André Luiz França Batista ${ }^{3}$, \\ Adriano Ribeiro de Mendonça ${ }^{4}$, Wilian Soares Lacerda ${ }^{5}$
}

(received: August 30, 2010; accepted: December 21, 2012)

\begin{abstract}
Energy is an important factor of economic growth and is critical to the stability of a nation. Charcoal is a renewable energy resource and is a fundamental input to the development of the Brazilian forest-based industry. The objective of this study is to provide a prognosis of the charcoal price series for the year 2007 by using Artificial Neural Networks. A feedforward multilayer perceptron ANN was used, the results of which are close to reality. The main findings are that: real prices of charcoal dropped between 1975 and 2000 and rose from the early 21st century; the ANN with two hidden layers was the architecture making the best prediction; the most effective learning rate was 0.99 and 600 cycles, representing the most satisfactory and accurate ANN training. Prediction using ANN was found to be more accurate when compared by the mean squared error to other studies modeling charcoal price series in Minas Gerais state.
\end{abstract}

Key words: Forest economics, time series, prediction.

\section{USO DE REDES NEURAIS ARTIFICIAIS PARA A PROGNOSE DOS PREÇOS DO CARVÃO VEGETAL EM MINAS GERAIS}

\begin{abstract}
RESUMO: A energia é um importante fator de crescimento econômico e vital para a estabilidade de uma nação. O carvão vegetal é um recurso energético renovável, um dos insumos básicos responsáveis pelo desenvolvimento das indústrias de base florestal no Brasil. Objetivou-se, neste artigo, fazer a prognose para o ano de 2007 da série de preços do carvão vegetal, utilizando as Redes Neurais Artificiais. Foi utilizada a RNA perceptron de camadas múltiplas, feed-forward, cujos resultados são próximos da realidade. Os principais resultados encontrados foram: os preços reais do carvão vegetal foram declinantes no período de 1975 a 2000 e crescentes a partir do inicio do século XXI; a arquitetura da Rede Neural Artificial que realizou melhor previsão foi a com duas camadas escondidas; a taxa de aprendizagem mais eficiente foi de 0,99 e 600 ciclos, que representou treinamento da RNA mais satisfatório e mais preciso. A previsão, usando a $R N A$, se mostrou mais precisa quando comparada pelo erro quadrático médio de previsão de outros estudos para a série de preços de carvão vegetal em Minas Gerais.
\end{abstract}

Palavras-chave: Economia florestal, séries temporais, previsão.

\section{INTRODUCTION}

Energy is a major factor of economic development and critical in promoting the stability of nations, yet its supply and use worldwide continues to be dominated by fossil fuels (ROVERE, 1996). The intensity and efficiency of energy use can help mitigate impacts on economic and population growth. Combined, these effects cause structural changes to the economy and to technological development, due to variations in input prices.

The iron and steel industry, both in Brazil and abroad, is by nature a critical and conditioning factor to economic growth. In such context, forest-generated energy has been and continues to be extremely important to the production of intermediate goods that in turn are essential raw materials for the development of the Brazilian industry sector (PAULA, 1992).

\footnotetext{
${ }^{1}$ Economist, Professor, DSc in Forest Engineering - Universidade Federal da Paraíba/UFPB - Centro de Energias Alternativas e Renováveis - Departamento de Engenharia de Energias Renováveis - Cx. P. 5115 - 58.051-970 - João Pessoa, PB, Brasil luiz@cear.ufpb.br

${ }^{2}$ Forest Engineer, Professor, PhD in Forest Economics - Universidade Federal de Lavras/UFLA - Departamento de Ciências Florestais - Cx. P. 3037 -37.200-000 - Lavras, MG, Brasil-jlprezen@dcf.ufla.br

${ }^{3}$ Computer Scientist, Professor, MSc in Systems Engineering - Instituto Federal do Triângulo Mineiro - Campus Ituiutaba - Rua do Córrego Pirapitinga, s/n, Novo Tempo II - 38.300-970 - Ituiutaba, MG, Brasil - andre.iftm@gmail.com

${ }^{4}$ Forest Engineer, Professor, DSc in Forest Engineering - Universidade Federal do Espírito Santo - Centro de Ciências Agrárias - Departamento de Engenharia Florestal - Av. Governador Lindemberg, 316, Centro - 29.550-000 - Jeronimo Monteiro, ES, Brasil - floresteiro_ufes@hotmail.com ${ }^{5}$ Electrical Engineer, Professor, DSc in Computer Engineering - Universidade Federal de Lavras/UFLA - Departamento de Ciências da Computação Cx. P. 3037 -37.200-000 - Lavras, MG, Brasil-lacerda@dcc.ufla.br
}

Cerne, Lavras, v. 19, n. 2, p. 281-288, abr./jun. 2013 
Charcoal is used as a reducing fuel and energy source in the smelting of iron ore in blast furnaces and production of pig iron. In 2006, 33.2\% of the pig iron produced in Brazil (32.5 million tons) had charcoal as reducing agent, $50 \%$ of which was sourced in native forests. More than $90 \%$ of the charcoal output produced in Brazil is destined for the iron and steel industry (ASSOCIAÇÃO BRASILEIRA DOS PRODUTORES DE FLORESTA PLANTADAS - ABRAF, 2008).

In Brazil, charcoal is mainly used for the production of pig iron and its supply is distributed across Minas Gerais (63\%), Polo Carajás/PA (31\%), Espírito Santo (5\%) and other states (1\%). In Brazil, $90 \%$ of the pig iron sold in the domestic market comes from Minas Gerais (HESS, 2008).

Globalization has prompted greater integration of production activities and has turned political, economic and social issues into strategies for the forestry sector which, in turn, is becoming more and more integrated and dynamic. In order to ensure more effective decisionmaking in that sector and in order for the market to be better planned, one should consider that the comparative advantages that Brazil undoubtedly has should rapidly become competitive advantages (REZENDE et al., 2008).

Booming or slumping of the international steel, pig iron and coke markets reflect on variations in charcoal demand. Abrupt changes in charcoal prices generate disruption in the supply of timber to meet the demands of the iron and steel market. A change to the right in the demand curve for steel will increase the need for basic inputs, including charcoal, and that can raise its equilibrium prices in the short term, until the market establishes new equilibrium conditions.

Charcoal supply is unstable, as the formation of forest areas depends on endogenous and exogenous conditions, which creates market imbalances (supply and demand). The behavior of charcoal prices in Minas Gerais could be differentiated as a function of the origin of timber, whether from native or from nonnative fastgrowing forests (eucalyptus) (COELHO JUNIOR et al., 2006b).

These present and future changes can be predicted by linear or nonlinear models. Time series models were used for analysis of charcoal prices by Silva and Pereira (1981), who analyzed price stationarity; by Bernades (1987), who noted a sharp cyclical tendency in that market in the medium term; by Rezende et al. (1988), who found maximum and minimum seasonal indices respectively in May and October, with an amplitude range of around $11 \%$.

Works on charcoal price predictions were written by Silva and Silva (1996), who applied the Box \& Jenkins method and found that ARIMA $(1,1,1)$ provided better fit than other conventional methods, although they did not include seasonal effects in the model, while Coelho Junior et al. (2006a) fitted seasonality models and found that SARIMA $(2,0,1)(0,1,1)_{12}$ provided good fits and a simple and frugal model.

The Artificial Neural Network (ANN) methodology is inspired by artificial intelligence and is being currently used in various branches of science, particularly in economics and medicine. ANNs have been used for solving statistical problems, both for transverse data (regression) and for time series or spatial data. The Artificial Neural Network concept was inspired by biological neural systems and by the learning capability of the human brain, for the ultimate purpose of solving problems (DAZZY, 1999).

ANNs reproduce the human brain functioning in a simplified way. The notions of memory functioning are inspired by associative principles, by means of which neural network models will provide good learning performances (KOHONEN, 1988).

One of the advantages of ANNs is that they do not require prior knowledge of data distribution to carry out analysis, and that distinguishes them from conventional statistical analysis. Neural networks can provide better performance than traditional statistical methods, even if their analytical and/or statistical representations are unknown, provided there is an underlying relationship between data (CASTRO, 2001).

ANN methodology is considered a recent tool in the field of prediction, particularly where there is a strong component of nonlinearity, as is the case with the behavior of charcoal prices over time. The objective of this work is thus to provide a prognosis of charcoal prices using ANNs.

\section{MATERIAL AND METHODS}

\subsection{Database and data handing}

This study was based on the monthly series of charcoal prices in Brazil (US\$/cubic meter) from January 1975 to December 2007. Prices are formed by the market of Minas Gerais state, as this is the largest producer and consumer of charcoal input. The price series was obtained 
from the statistical yearbooks Anuários Estatísticos da Associação Brasileira de Florestas Renováveis ABRACAVE (2003), now renamed Associação Mineira de Silvicultura (AMS).

The market prices of charcoal were converted into U.S. dollars, using the official marketability value set by the central bank of Brazil - BACEN (PTAX 800) at sale price (dollar sold by BACEN in the domestic market) (BANCO CENTRAL DO BRASIL, 2008), and then deflated by the Consumer Price Index (CPI), reference year Dec/2005 $=100$, as obtained from the Bureau of Labor Statistics (BUREAU OF LABOR STATISTIC - BLS, 2008).

The sampling period (1975 to 2007) comprises 396 data pieces of monthly prices. The first portion, 384 data pieces, was used for fitting the neural network (input values), that is, monthly data from January 1975 to December 2006. The months January to December 2007 were reserved for validating the prognosis model. The software used was SCILAB 4.1.2.

\subsection{Artificial Neural Networks (ANN)}

Haykin (1999) defines ANN as processors having a natural propensity for storing knowledge derived from experience, resembling a human brain in two aspects: knowledge is acquired by the network through a learning process and the strengths of connection between the nodes, known as synaptic weights, are used for storing such knowledge.

The primary component of that model is the processing unit, also known as node, neuron or cell (Figure 1).

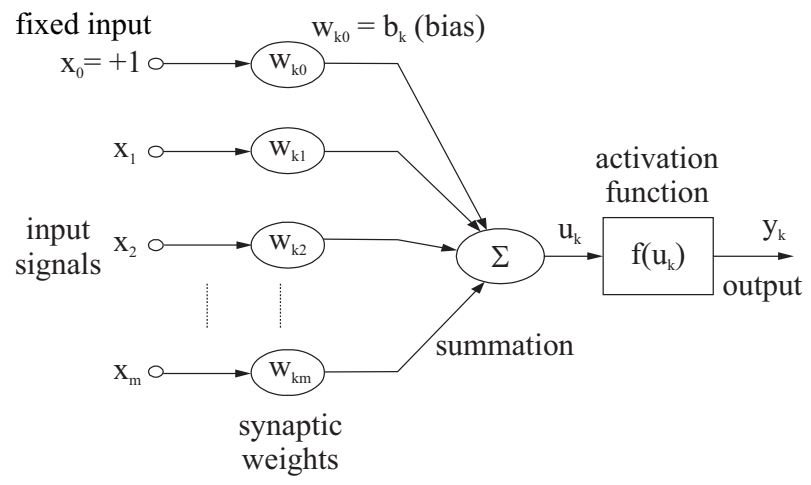

Figure 1 - Artificial neuron.

Figura 1 - Neurônio artificial.

Source: Calöba et al. (2002).
The underlying principle of artificial neuron functioning is summarized as follows:

a) Signals are applied to the input $\left(x_{1}\right.$, $\left.x_{m}\right)$, in this case $\mathrm{x}_{1}$ to $\mathrm{x}_{12}$, which are the monthly prices of charcoal from January 1975 to December 2006;

b) Each signal is multiplied by a weight that denotes its influence on the output of the unit $\left(w_{k}\right)$;

c) A weighted sum of the signals is computed to derive an activity level $\left(u_{k}\right)$;

d) The activation function $f\left(u_{k}\right)$ determines the output and introduces non-linearity to the model;

e) Bias $b_{k}$ is used for increasing or decreasing the influence of input values;

f) The bias can be considered a constant input of 1 , multiplied by a $b_{k}$ weight,

This processing unit is a mathematical model inspired by the biological model of a neuron. The output variable $\left(y_{k}\right)$ of the artificial neuron, with values predicted for the period January to December 2007, is given as:

$$
y_{k}=f\left(u_{k}\right)=f\left(\sum_{j=1}^{m} w_{k j} x_{j}+b_{k}\right)
$$

or considering the bias as an input of value $\mathrm{x}_{0}=1$ and weight $\mathrm{w}_{\mathrm{k} 0}=\mathrm{b}_{\mathrm{k}}$,

$$
y_{k}=f\left(u_{k}\right)=f\left(\sum_{j=0}^{m} w_{k j} x_{j}\right)
$$

Typically, an Artificial Neural Network comprises an input layer (observed values of the relevant series) that receives stimuli, and an output layer that generates the desired response (predicted values). Some networks may have one or more internal layers (also known as intermediate or hidden layers).

Figure 2 illustrates an artificial neural network of the multilayer perceptron type, allowing the user to perform tasks such as predictions, simulations, among other applications. Its architecture consists of neuron layers that interconnect through synaptic connections.

Each neuron in one layer has directed connections to every neuron of the subsequent layers. Synaptic weights are connections that transform the signal, activating the input neurons through the internal layers up until the output layer, where the desired response is obtained (MEDEIROS, 2003).

Cerne, Lavras, v. 19, n. 2, p. 281-288, abr./jun. 2013 


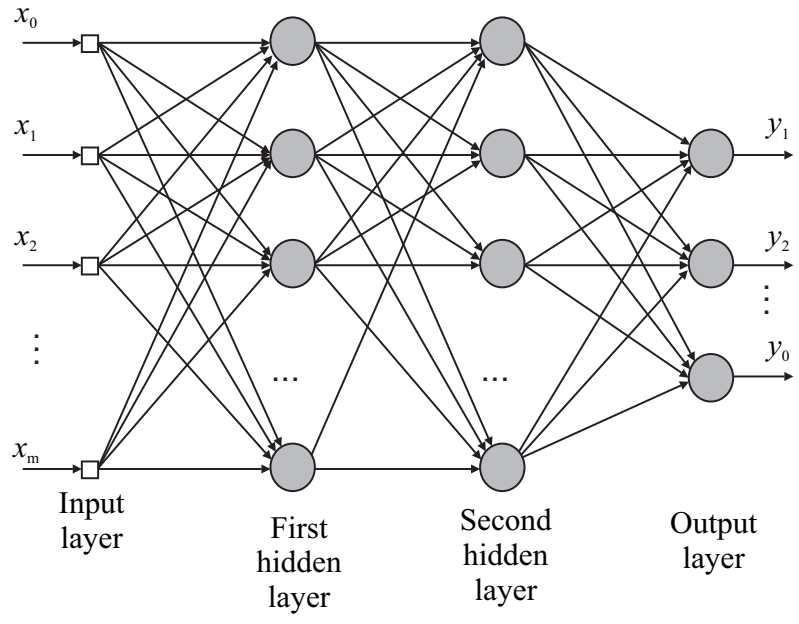

Figure 2 - A feedforward multilayer network (Multilayer Perceptron - MLP).

Figura 2-Rede feedforward de Múltiplas Camadas (Multilayer Perceptron - MLP).

Source: Freitas and Souza (2004).

\subsubsection{Architecture of a neural network}

A neural network can group neurons through layers, whether directed or not, with forward connections in one direction. Where networks are only connected forwardly, they are termed feedforward networks and are divided into monolayer and multilayer networks (FREITAS; SOUZA, 2004).

The computational capability of a neural network lies in its connections and between the processing elements. Weights weigh each connection and store the information learned by the network.

The foundations of the learning process of a neural network are:

a) Training or Learning: procedures that can be performed for a given function to fit the parameters of the neural networks.

b) Number of cycles (or epochs): how many times, during weight update, the training patterns will be presented to the neural networks.

c) Learning rate: controls the changes to weight strength, that is, a high learning rate accelerates the process, which may reduce the generalization capability of a neural network.

In a dynamic environment, neural networks are very flexible tools. They have extremely desirable characteristics when it comes to prognosis of time series, since they have a capability to quickly learn complex data patterns and trends as well as to adapt quickly to changes (CASTRO, 2001).

MLP networks offer advantages if used in time series, for the reason that this type of topology is capable of performing reliable prognoses of future values. Figure 3 illustrates the processing routine of a MLP neural network.

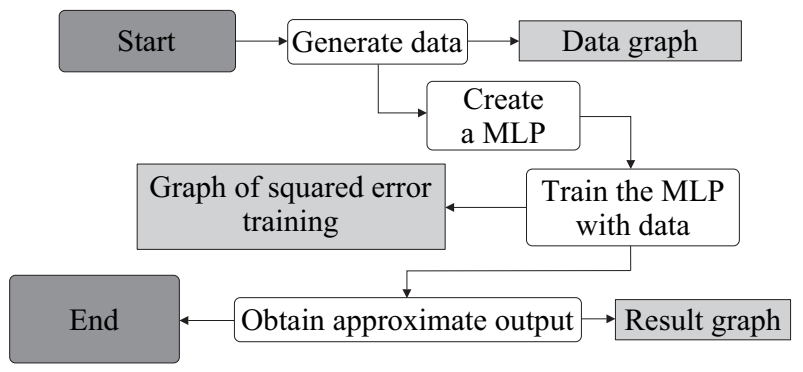

Figure 3 - Processing routine of an artificial neural network.

Figura 3 -Rotina de processamento de rede neural artificial.

Training with many epochs creates a problem known as overtraining, and that may lead to network specialization, which happens when there are few data available, translating as loss of network capability to respond well to unseen data (loss of generalization capability).

In the typical development of a network error throughout the training process, whether of the training set or testing set, from a certain number of steps (training) the performance of the testing set stops to decline and prediction starts to worsen, even if the performance of the training set continues to decline. That is when overspecialization begins.

In order to verify whether the amount of training required to attain good performance and to validate the neural network for better representing prediction, the mean squared error of prediction was used, given as follows:

$$
E Q M P=\frac{1}{n} \sum_{i=1}^{n}(Y d-Y)^{2}
$$

where,

$E Q M P=$ mean squared error of estimator

$\mathrm{Y}=$ observed value

Yd = estimated value

$\mathrm{n} \quad=$ number of samples

Cerne, Lavras, v. 19, n. 2, p. 281-288, abr./jun. 2013 
The best artificial neural network is the one providing the lowest validation error, that is, the network having the lowest error for the testing set (EQMP). The validation set corresponds to input-output pairs not applied to the network during training and not considered a parameter to stop training, in other words, it represents an entirely new set to be applied to the network in order to evaluate its performance.

\section{RESULTS AND DISCUSSION}

Figure 4 provides the series of charcoal prices for the period January 1975 to December 2007. The instability of prices over time was due to endogenous and exogenous variables in the forest setting. In the 1970s, oscillations such as international economic crises, particularly the Oil Crisis II (1979), influenced this market. Energy policies practiced in the sixties and seventies reflected in the early 1980s as a downward trend in charcoal prices.

With the end of the military regime in 1985, the Brazilian government sought to establish a new economic order ultimately looking to control inflation, which led to several economic policies and five changes to the national unit of currency. Most currency changes consisted of cutting zeros, in other words, one new monetary unit was worth a thousand old monetary units.

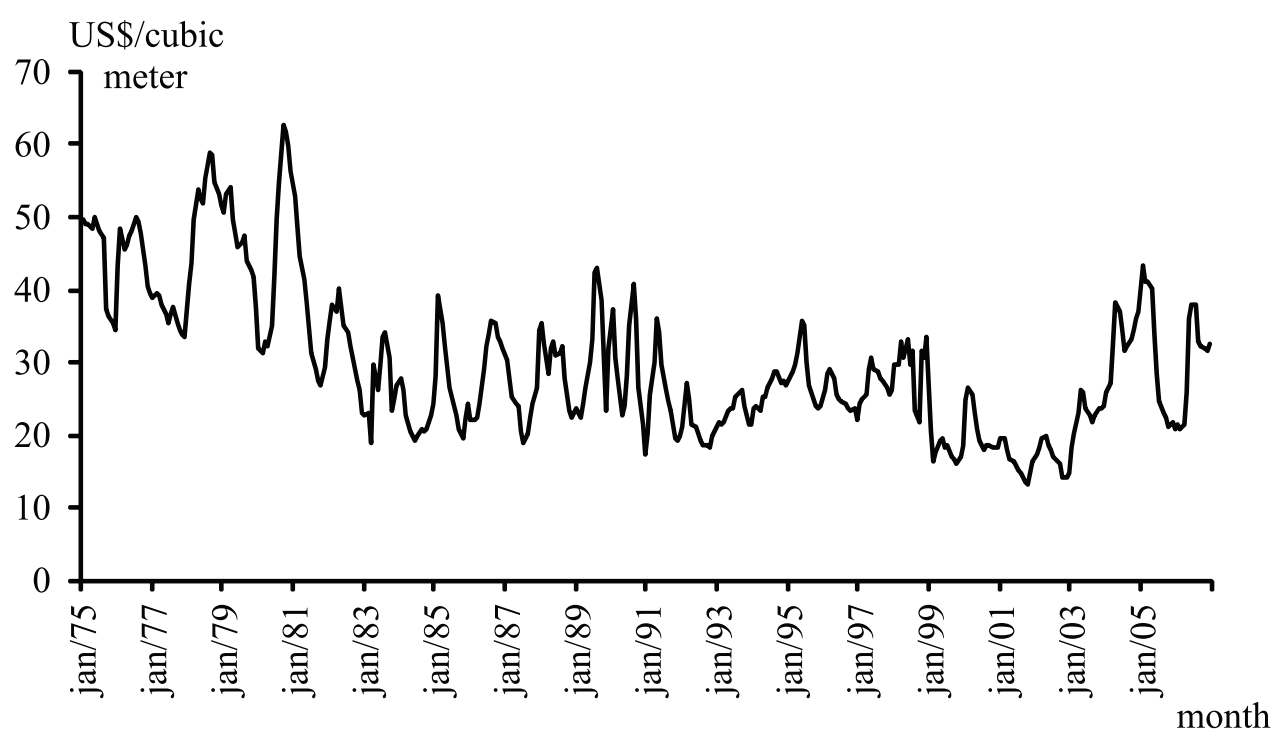

The 'Plano Real' plan (February 1994) brought a more sophisticated change and has been in force until the present day, introducing the 'URV' unit (real value unit), which coexisted with the 'Cruzeiro Real' unit $(\mathrm{CR} \$)$ for a certain period, both being finally replaced by the 'Real' unit (R\$). The conversion rate of 'Cruzeiro Real' to 'Real' was Cr\$2,750.00/R $\$ 1.00$, while the rate of 'URV' to 'Real' was one to one.

With the end of tax incentives for reforestation in 1988, independent farmers stopped growing their own crops due to lack of incentive from the government. Among the forest crops that remained were those from integrated industries. The 1990s were hit by several world crises, especially in countries like Brazil, Russia, India and China, known as BRIC countries, among other countries, which started to flourish with a great international potential.

In the early 21 st century, international trade boomed at a rapid pace, driven by the BRIC countries, prompting a rise in oil prices up to a point where they reached three digits and increasing the international demand for steel. These factors contributed to the rise in the real price of charcoal in the same period, as illustrated in Figure 4.

The increase in charcoal consumption is directly related to international development and is also associated with environmental pressures, in particular the clean development mechanisms. 
In search for an Artificial Neural Network capable of meeting this charcoal price series for making a prediction, various ANN architectures were used, according to Table 1 .

Table 1 - Architecture of the Neural Networks tested and respective mean squared errors of the estimator (EQMP).

Tabela 1 - Arquitetura das Redes Neurais testadas e seus erros quadráticos médios de previsão (EQMP).

\begin{tabular}{ccccccccc}
\hline \multicolumn{3}{c}{ ANN } & EQMP & \multicolumn{3}{c}{ ANN } & EQMP \\
\hline 13 & 50 & 1 & 0.0007069 & 13 & 30 & 30 & 1 & 0.0005620 \\
\hline 13 & 30 & 1 & 0.0006632 & 13 & 30 & 20 & 1 & 0.0005678 \\
\hline 13 & 20 & 1 & 0.0005516 & 13 & 20 & 20 & 1 & 0.0006072 \\
\hline 13 & 15 & 1 & 0.0005863 & 13 & 20 & 10 & 1 & 0.0006152 \\
\hline 13 & 10 & 1 & 0.0006864 & 13 & 10 & 05 & 1 & 0.0005950 \\
\hline 13 & 07 & 1 & 0.0006260 & 13 & 05 & 05 & 1 & 0.0005367 \\
\hline 13 & 05 & 1 & 0.0005819 & $\mathbf{1 3}$ & $\mathbf{0 5}$ & $\mathbf{0 3}$ & $\mathbf{1}$ & $\mathbf{0 . 0 0 0 5 1 2 6}$ \\
\hline 13 & 03 & 1 & 0.0006305 & 13 & 03 & 02 & 1 & 0.0005256 \\
\hline
\end{tabular}

Source: Results of research.

The learning rate of the ANN was set at 1 (one) and 600 (six) cycles was the selected amount to compare the architectures being tested. Table 1 shows that architectures with only one hidden layer had higher mean errors in comparison with architectures with two hidden layers. The best architecture showing the lowest squared error of estimator was the ANN with two hidden layers, i.e. with 05 (five) neurons in the 1st hidden layer and 03 (three) neurons in the 2nd hidden layer.

Once the architecture of the ANN was determined as $13-5-3-1$, the learning rate was modeled. Rates used were $0.99,0.05$ and 0.0001 . A higher hit rate was noted for a learning rate close to 1 (one).

Figure 5 illustrates the training cycles on which the weights of the Neural Network were modeled. It was noted that from 1,000 (a thousand) cycles (epochs) the training error remains constant, yet with 600 (six hundred) cycles (epochs) a lower mean squared error was found, as already illustrated in Table 1 .

Figure 6 provides the prognosis for year 2007 modeled by the ANN $13-5-3-1$. It was found that predictions made by the feedforward Artificial Neural Network with two hidden layers provided results very close to reality.

To check the predictability power of this model, using artificial neural networks, works were sought in literature on forest economics that covered charcoal price modeling in Minas Gerais (Table 2), looking to compare the degrees of accuracy. Each of these works was developed using differed periods, currencies and indexation points in time.

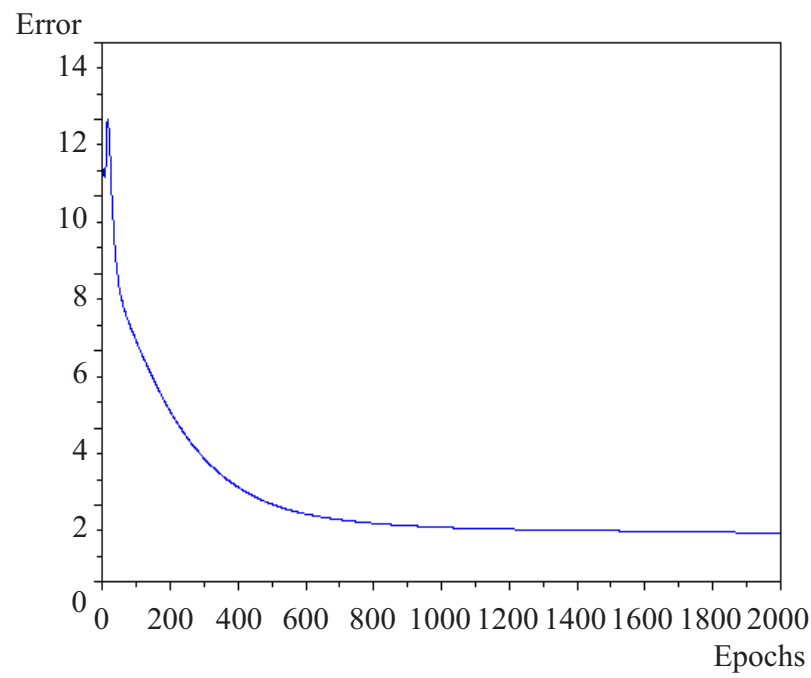

Figure 5 - Training iterations (epochs) of the ANN (13-5-3-1).

Figura 5-Ciclos de treinamento (épocas) da RNA (13-5-3-1).

Cerne, Lavras, v. 19, n. 2, p. 281-288, abr./jun. 2013 
US\$/cubic meter

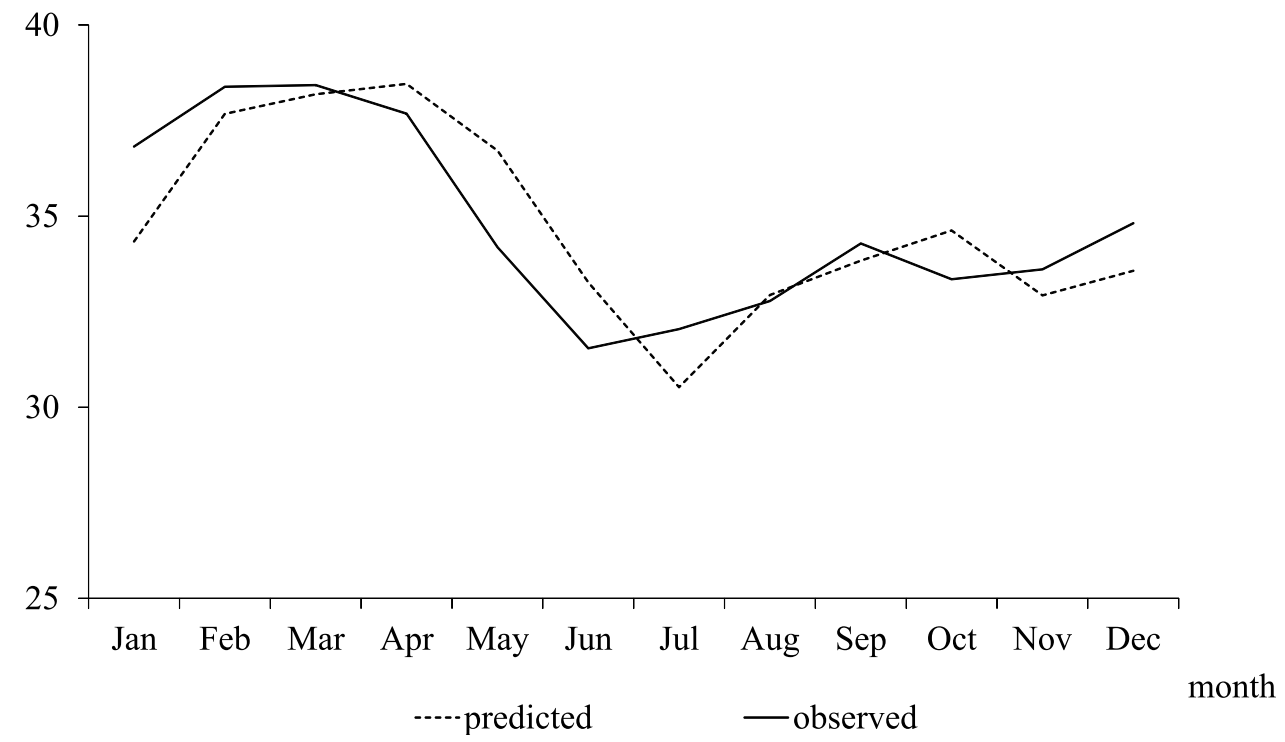

Figure 6 - Prediction of the ANN (13-5 - 3 - 1) for charcoal prices in the year 2007.

Figura 6 - Previsão da RNA (13-5 - 3-1) para os preços do carvão vegetal, para o ano de 2007.

Table 2 - Works developed for modeling of charcoal prices in Minas Gerais.

Tabela 2 - Trabalhos desenvolvidos para previsão de preços de carvão vegetal em Minas Gerais.

\begin{tabular}{lcc}
\hline Author (year) & Methodology & EQMP \\
\hline Silva and Silva (1996) & ARIMA $(1,1,1)$ & - \\
$\begin{array}{l}\text { Coelho Junior et al. } \\
\text { (2006a) }\end{array}$ & SARIMA $(2,0,1)$ & 4.07 \\
Proposed model & ANN $13-5-3-1)_{12}$ & \\
\hline
\end{tabular}

The proposed model was checked for better or worse fitting, and to find whether artificial neural networks do make better predictions or not. Table 2 shows that the ANN 13-5-3-1 improved prediction accuracy for the charcoal price series. The mean squared error (EQMP) of the proposed model is lower in comparison with the works of other authors, thus providing superior modeling of the charcoal price series in Minas Gerais state.

\section{CONCLUSIONS}

Real prices of charcoal declined from 1975 to 2000 and increased from the early 21 st century;
The ANN architecture providing the best prediction was the network with two hidden layers;

The most effective learning rate was 0.99 and 600 cycles, providing the most satisfactory and accurate ANN training.

Prediction using ANN was found to be more accurate for modeling the charcoal price series in Minas Gerais state, when compared by the mean squared error to other methodologies used for the same purpose.

\section{REFERENCES}

ASSOCIAÇÃO BRASILEIRA DE FLORESTAS RENOVÁVEIS. Anuário estatístico. Belo Horizonte, 2003.

ASSOCIAÇÃO BRASILEIRA DOS PRODUTORES DE FLORESTA PLANTADAS. Anuário estatístico da ABRAF: ano base 2008. Brasília, 2009. 90 p.

BANCO CENTRAL DO BRASIL. Séries históricas. Brasília, 2008. Disponível em: <http://www.bcb.gov.br/sérieshitoricas>. Acesso em: 15 jun. 2008.

BERNARDES, P. Análise do comportamento de preço de carvão vegetal nativo. In: ENCONTRO TÉCNICO FLORESTAL, 3., 1987, Montes Claros. Anais... Montes Claros: IPEF, 1987. p. 1-8.

Cerne, Lavras, v. 19, n. 2, p. 281-288, abr./jun. 2013 
BUREAU OF LABOR STATISTIC. Consumer price índex. Washington: Department of Labor, 2008. Disponível em: $<\mathrm{ftp}: / / \mathrm{ftp}$. bls.gov/pub/special. request/cpi/cpiai.txt>. Acesso em: 15 jun. 2008.

CALÔBA, G. M.; CALÔBA, L. P.; SALIBY, E. Cooperação entre redes neurais artificiais e técnicas 'clássicas' para previsão de demanda de uma série de vendas de cerveja na Austrália. Pesquisa Operacional, Rio de Janeiro, v. 22, n. 3, p. 345-358, 2002.

CASTRO, M. C. F. Predição não-linear de séries temporais usando redes neurais $R B F$ por decomposição em componentes principais. 2001. 186 p. Tese (Doutorado em Engenharia Elétrica) - Universidade Estadual de Campinas, Campinas, 2001.

COELHO JUNIOR, L. M.; REZENDE, J. L. P.; SÁFADI, T.; CALEGARIO, N. Análise longitudinal dos preços de carvão vegetal no Estado de Minas Gerais. Revista Árvore, Viçosa, v. 30 , n. 3 , p. $39-48$, abr. 2006 a.

COELHO JUNIOR, L. M.; REZENDE, J. L. P.; SÁFADI, T.; CALEGARIO, N. Análise temporal do preço do carvão vegetal oriundo de floresta nativa e de floresta plantada. Scientia Forestalis, Piracicaba, v. 30, n. 3, p. 429-438, 2006 b.

DAZZY, R. L. S. Sistemas especialistas conexionistas: implementação por redes diretas e bidirecionais. 1999. 135 p. Dissertação (Mestrado em Ciência da Computação) Universidade Federal de Santa Catarina, Florianópolis, 1999.

FREITAS, S. O. de; SOUZA, A. A. de. Utilização de redes neurais na precificação de opções. Resenha BM\&F, Rio de Janeiro, n. 150, p. 63-73, 2004. Disponível em: <http://www. nyse.com.br/papers/1402200210H10.pdf>. Acesso em: 13 abr. 2009.

HAYKIN, S. Neural networks: a comprehensive foundation. New Jersey: Prentice Hall; Upper Saddle River, 1999. 218 p.
HESS, S. C. Siderurgia brasileira depreda florestas. Disponível em: <http://www.riosvivos.org.br/ arquivos/838513513.pdf>. Acesso em: 17 jun. 2008.

KOHONEN, T. An introduction to neural computing. Neural Networks, Edinburgh, v. 1, p. 3-16, Apr. 1988.

MEDEIROS, L. F. Redes neurais em Delphi. Florianópolis: Visual Books, 2003. 115 p.

PAULA, G. M. Consumo de energia na siderurgia brasileira. In: ENCONTRO NACIONAL DE ECONOMIA, 20., 1992, Campos do Jordão. Anais... Campos do Jordão: ANPEC, 1992. 1 CD-ROM.

REZENDE, J. L. P.; COELHO JUNIOR, L. M.; BORGES, L. A. C. Madeira e derivados: oportunidades do Brasil no mercado internacional. In: OLIVEIRA, J. T. S.; FIEDLER, N. C.; NOGUEIRA, M. (Ed.). Tecnologias aplicadas ao setor madeireiro III. Jerônimo Monteiro: Suprema, 2008. p. 11-42.

REZENDE, J. L. P.; SILVA, A. A. L.; BARROS, A. A. A. Variação estacional dos preços do carvão vegetal no Estado de Minas Gerais, período de 1981-1987. Revista Árvore, Viçosa, v. 12 , n. 2 , p. 146-155, mar./abr. 1988.

ROVERE, E. L. L. Energia e meio ambiente. In: MARGULIS, S. (Ed.). Meio ambiente: aspectos técnicos e econômicos. 2. ed. Brasília: IPEA, 1996. p. 11-34.

SILVA, M. L.; SILVA, J. M. A. Análise do comportamento temporal dos preços do carvão vegetal: aplicação do modelo e a avaliação da metodologia "Box and Jenkins". Revista Árvore, Viçosa, v. 20, n. 1, p. 57-67, jan./fev. 1996.

SILVA, O. M.; PEREIRA, A. R. Variação estacional dos preços do carvão vegetal no Estado de Minas Gerais. Revista Árvore, Viçosa, v. 5, n. 2, p. 125-34, jul./dez. 1981. 